\title{
Developing EFL Students' Critical Thinking Competence in English Reading Class
}

\author{
Yi Zhang \\ School of Humanity, Tiangong University, Tianjin, China \\ Email: zhangyi419@126.com
}

How to cite this paper: Zhang, Y. (2020). Developing EFL Students' Critical Thinking Competence in English Reading Class. Creative Education, 11, 1145-1151. https://doi.org/10.4236/ce.2020.117085

Received: March 20, 2020

Accepted: July 25, 2020

Published: July 28, 2020

Copyright $\odot 2020$ by author(s) and Scientific Research Publishing Inc. This work is licensed under the Creative Commons Attribution International License (CC BY 4.0).

http://creativecommons.org/licenses/by/4.0/

\begin{abstract}
The Education Ministry requires that English majors at university level in China should not only achieve a good English language competence, but also a fair critical thinking ability in order to develop their intercultural communicative competence. However, various studies reveal that in China the perceived critical thinking competence of language majors at university level is weak. Given the context, this paper aims at proposing an eclectic paradigm to improve learners' critical thinking competence in English Reading class, by presenting the status quo and the root causes of weak critical thinking ability of EFL students in China, and drawing on various theoretical concepts.
\end{abstract}

\section{Keywords}

Critical Thinking, Critical Reading Strategies, EFL (the Acronym for "English as a Foreign Language"), Bottom-Up Approach, Top-Down Approach

\section{Introduction}

In 2000, the Revised National English Language Curriculum for English Majors issued by Ministry of Education of the People's Republic of China requires that English majors at university level in China should not only achieve a good English language competence, but also a fair critical thinking ability in order to develop their cross-cultural communicative and critical thinking competence. In this regard, students' critical thinking abilities play a critical role in enabling them to engage in a fruitful communicative activity in EFL class.

Various studies, however, reveal that in China the perceived critical thinking competence of language majors at university level is weak (Wen, 2010; Gong, 2019). Students' deficiency in their critical thinking ability may cast doubt on the effective outcomes of the classroom-based communicative activities. 
Given that context, teachers are required to pay more attention to cultivating students' ability of absorbing knowledge, thinking independently and critically. By presenting the rationale and the status quo of weak critical thinking ability of EFL students in China, this paper addresses how to develop Chinese learners' critical competence in EFL education at university level.

\section{Critical Thinking and ESL/EFL Education}

In contrast to rote memorization, Paul (2010) states "critical thinking, in contrast to rote memorization or simple information recall, has as its goal, the stimulation of analytical and evaluative processes of the mind". Moore \& Parker (2008) define critical thinking as "the careful and deliberate determination of whether to accept, reject, or suspend judgment about a claim”. They also consider that critical thinking involved several skills or abilities, including the ability to listen and read carefully, to evaluate arguments, to look for and find hidden assumptions, and to trace the consequences of a claim.

Some researchers point out that since not all cultures value critical thinking to the same extent, and in those cultures where it is not highly valued, critical thinking is unlikely to enhance one's command of the language or one's ability to command others through language (Atkinson, 1997).

However, Ruminski \& Hanks (1995) advocate that teachers should have a clear concept of critical thinking for the purpose of teaching and evaluation. Ennis (1996) also argues that the problem for educators is really one of how and when to introduce critical thinking, not whether or not critical thinking has value for people belonging to other cultures. Davidson (1998) claims that in spite of the fact that many societies discourage criticism in some contexts, such as religious and political fields, this does not mean that critical thinking is entirely absent from these societies.

Although Atkinson makes a valuable appraisal of whether it is appropriate to bring critical thinking instruction into the classroom, his concerns are misplaced. If critical thinking is a culturally based concept, the EFL classroom would be one of the appropriate places for critical thinking instruction. Learning a language is not merely a matter of vocabulary and grammatical rules, but learning another culture and way of looking at the world (Byram, 1989).

\section{Critical Thinking of Chinese EFL Students and the Revised Curriculum}

In China, EFL teachers did not have to concern themselves with the instruction of critical thinking skills in class. Wen Qiufang (2010), a senior Chinese EFL researcher, points out:

EFL teaching [at various levels] in the Chinese context has placed much emphasis on developing students' basic linguistic skills by imitating intonation and pronunciation, reciting chunks of a good English passage and memorizing words and pattern drills. What is ignored in EFL teaching is the fostering of students' critical thinking and problem-solving ability. 
Critical thinking ability was not officially included into the EFL pedagogy until the revised national curriculum of English language education for English majors at tertiary level, which requires that English majors need to develop their intercultural communicative competence and also their critical thinking abilities within their EFL education. Consequently, an important question is raised: how to teach critical thinking in EFL programmes at tertiary level in China.

\section{Eclectic Model for Critical Thinking Development}

From the following considerations, the course of the Comprehensive English (Reading) is chosen to demonstrate the effectiveness of the eclectic model. First, for the first 2 years of the undergraduate program of English majors, it accounts for about $57 \%$ of 1100 class hours designed for English skill-based courses. Second, as one of the significant curriculum for students of both English majors and non-majors, it is supposed to employ multiple language skills and cross-cultural awareness.

This approach is different from the traditional one, in which teachers tend to elaborate over-meticulously upon new words, phrases and sentence structure patterns, while the gist of the text is usually overlooked (Xiao, 2009). As shown in Figure 1 below.

Comprehensive English (Reading) of the eclectic approach helps overcome the weakness of teacher-centeredness, but treats English teaching and learning as an organic process, combining reading at the syntactical level (bottom-up stage) with the textual and discourse level (top-down stage), focusing on different tasks on performing pre-reading, while-reading and post-reading. This combination is to cultivate learners' competence to think critically as required by the new curriculum.

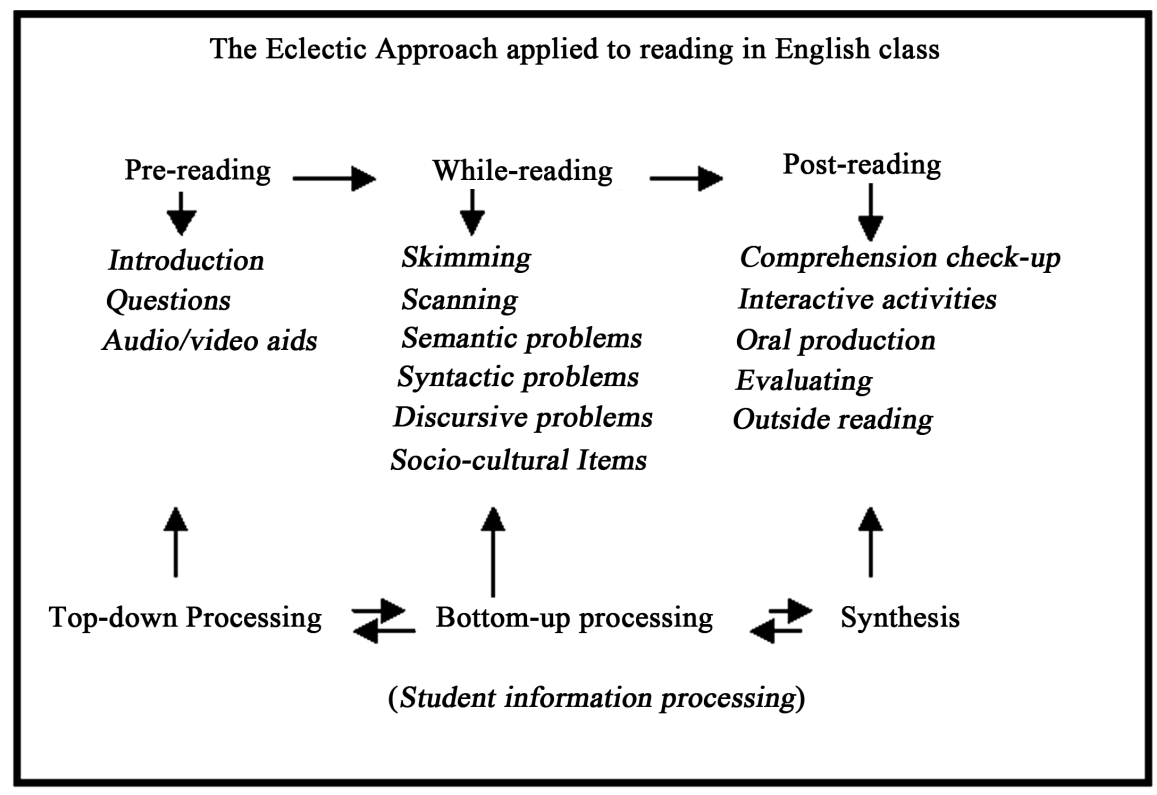

Figure 1. Eclectic model to teach English reading (Xiao, 2009). 


\subsection{Pre-Reading Stage}

Nuttall (1996) classifies classroom questions into six types from teaching perspective:

1) Questions of literal comprehension: those whose answers are directly and explicitly expressed in the text. They can often be answered in the words of the text.

2) Questions involving reorganization or reinterpretation: those requiring students either to reinterpret literal information or to obtain it from various parts of the text and put it together in a new way, using elementary inferring.

3) Questions of inference: those obliging students to consider what is implied but not explicitly stated.

4) Questions of evaluation: those asking for a considered judgement about the text in terms of what the writer is trying to do and how far $\mathrm{s} /$ he has achieved it.

5) Questions of personal response: those whose answers depend least on the writer but record reader's reaction to the text.

6) Questions concerned with how writers say what they mean: those intending to give students strategies for dealing with a text in general.

At this stage, teachers will start the lesson with thought-provoking questions, which relate students' reading activity to their prior knowledge and experience, to encourage students to make predictions about the content of the text, and help students better understand the passage they are going to read. But it is important that teachers should be aware of what to ask and how to ask appropriately based on the comprehension and linguistic proficiency of learners. The way teachers ask questions ought to stimulate learners to think, to speak, to predict, to judge and to analyse. Nuttall's classification can help teachers raise appropriate questions which help students understand local and global meaning of a text as well as how these meanings are expressed. For instance, questions beginning with When, Where, Who, and What can prompt students to look for specific information from the reading material while those with Why and How can help them to probe more deeply into the information they are to read.

In teaching an English text entitled International Trade, we assigned students the following questions before they read the text:

1) What are the reasons for international trade?

2) Why is it impossible for any nation in the world to be self-sufficient?

3) What countries are mentioned in the text (if any)?

4) Why does the writer mention these countries?

It is crucial that teachers should not have preconceived rigid notions about "correct" answers to their questions. Instead, they should allow student input to be genuine, and possibly, unpredictable (Slaght, 2019).

\subsection{While-Reading Stage}

This stage consists of first reading, by skimming and scanning, and second reading, the problem-solving process. Skimming facilitates text process by initiating students into the gist and organization of the text, and scanning is helpful 
for seeking specific information for the pre-reading questions mentioned above. The problems to be solved in the second process may include lexical, syntactic, discourse, and socio-cultural dimensions (Xiang \& Wang, 1999).

As for discourse analysis, it is carried out through two aspects: firstly, how an idea is developed (such as topic sentence and support, cause and effect, comparison and contrast, generalizations and specifics, cohesion and coherence); secondly, how one idea leads to another (introduction, development, and conclusion). Students are guided and encouraged to employ different reading strategies, such as questioning, analytical, inductive and deductive methods, to practise their analytical and critical thinking skills.

With socio-cultural dimensions, cultural background knowledge should be provided at this stage to narrow the cross-cultural gap to help students to gain a better comprehension of the content, and "build new culture-specific schemata that will be available to EFL students outside the classroom" (Carrell \& Eisterhold, 1987). It will make the students more culturally sensitive when they are reading.

\subsection{Post-Reading Stage}

After reading the text of International Trade, the teacher asked the students a question to evaluate what does this writer contribute to your understanding of international trade? They were required not merely to give their response, but to discover the reasons and the presumed intention of the writer. To answer the question, they could not ignore the textual evidence to figure out the messages the writer intended to convey. These activities and tasks may be carried out in group-work, pair work, individual work and role play.

Tang (2009) claims claim that "reading ability must go beyond pure language skills and includes readers' pragmatic skills to interpret the text in terms of their knowledge and experience of the world". In this sense, the post-reading tasks focus on learners' ability to use target language to interpret the writers' intention, and to evaluate the effectiveness of the text. Their responses should be incorporated, in an identifiable fashion, into the learning process, in which students are encouraged to make judgments on what they read and to express their own opinions, and their dependence on teachers are reduced for the correct answers. Their ability to analyse and think critically will improve along the way.

\section{Suggestions and Implications for EFL Learners}

Many students might be familiar with some of critical reading strategies, but few of them use them consciously unless they are required to do so. Therefore, more emphasis should be placed on seeking more occasions to train them to employ critical reading strategies consciously and regularly.

In addition, students should be given more chances or time to play the active role, either individually or in group work, to apply critical reading strategies in their reading process. 


\section{Conclusion}

Without engaging their critical thinking abilities, the improvement on Chinese EFL learners' critical reading would not happen when teachers deposit knowledge in their heads. In a narrow sense, developing critical thinking ability is an effective way for students to overcome the superficiality of classroom discussion on a given topic. Only when students feel that they have something solid to say, and know how to say it, will they be able to engage in meaningful group activities with their peers in English class.

In a broad sense, it can be seen that English language instruction and critical thinking pedagogy are inter-related, integrated and complementary to each other. The implementation of one approach entails enhancement of the other.

\section{Funding}

Funded by "Project on the Integration of Industry, Education and Research of Chinese Ministry of Education” (Project No. 201902184007).

\section{Conflicts of Interest}

The author declares no conflicts of interest regarding the publication of this paper.

\section{References}

Atkinson, D. (1997). A Critical Approach to Critical Thinking in TESOL. TESOL Quartely, 31, 71-94. https://doi.org/10.2307/3587975

Byram, M. (1989). From Language Education for Intercultural Citizenship. Essays and Reflections. Clevedon: Multilingual Matters.

Carrell, P. L., \& Eisterhold, J. C. (1987). Schema Theory an ESL Reading Pedagogy. In M. H. Long, \& J. C. Richards (Eds.), Methodology in TESOL: A Book of Readings (pp. 218-230). New York: Newbury House Publishers.

Davidson, B. W. (1998). A Case for Critical Thinking in the English Language Classroom. TESOL Quarterly, 32, 119-123.

Ennis, R. (1996). Critical Thinking. Upper Saddle River, NJ: Prentice-Hall.

Gong, L. L. (2019). Basic Readings in Scientific English. Beijing: China Electric Power Press. Moore, B. N., \& Parker, R. (2008). Critical Thinking (9th ed.). New York: McGraw-Hill.

Nuttall, C. (1996). Teaching Reading Skills in a Foreign Language. Oxford: Heinemann.

Paul, R. (2010). Critical Thinking Competency Standards Essential for the Cultivation of Intellectual Skills. Journal of Developmental Education, 34, 38-39.

Ruminski, H. J., \& Hanks, W. E. (1995). Critical Thinking Lacks Definition and Uniform Evaluation Criteria. Journalism \& Mass Communication Educator, 50, 4-11. https://doi.org/10.1177/107769589505000302

Slaght, J. (2019). Reading English for Academic Study. Beijing: Foreign Language Teaching and Research Press.

Tang, G. J. (2009). Developing Critical Reading Training in English Reading Class. Journal of Southwest University, No. 35, 181-183. 
Wen, Q. F. (2010). Research on the Trend, Characteristics, Problems and Countermeasures of College English Teachers' Professional Development. Foreign Language in China, No. 4, 77-83.

Xiang, O. J., \& Wang, Y. M. (1999). Towards a Realization of a Holistic Model of Teaching Reading in the EFL Class in China. Teaching English in China, No. 36, 46-50.

Xiao, L. X. (2009). A New Paradigm of Teaching English in China: An Eclectic Model. The Asian EFL Journal, No. 1, 273-293. 